\title{
On the Human Challenges of Multiliteracies Pedagogy
}

\author{
ROB SIMON \\ Ontario Institute for Studies in Education, \\ University of Toronto, Canada
}

\begin{abstract}
Drawing on examples from classroom practice, this article explores implications of regarding multiliteracies pedagogy in early childhood settings as relationally and culturally situated. The author argues that investigating human dimensions of multiliteracies pedagogy involves interrogating assumptions about children and their capacities-viewing their cultural legacies and languages as powerful resources for teaching and learning, embedded in social contexts and relationships - as well as teachers-considering their positions in classrooms as sites from which theories of literacy learning can not only be applied, but also developed.
\end{abstract}

\section{Promising Technologies and the Social Realities of Teaching}

Malcolm Gladwell began his convocation address at University of Toronto with a story:

Over the course of World War II, the United States spent in excess of 1.5 billion dollars on developing technology that promised to deliver bombs with pinpoint accuracy. Developers of the Norden bombsight assured that American pilots could 'put a bomb into a pickle barrel from twenty thousand feet'. (Gladwell, 2011)

This indeed proved possible - in laboratory-perfect conditions. In real-world situations, the bombsight more often missed its mark. Gladwell used the story of the Norden bombsight to raise questions about new technologies and the claims of their designers and advocates that they can provide quick fixes to complex problems:

When the revolutions in the Middle East began last fall, people said, 'This is the result of Facebook and Twitter.' Along the same lines, there are people who say, 'If only we can come up with the right kinds of software, we can educate every child properly ...' Social media does not create revolutions. It's a tool. Nothing more or less. Real revolutions are born out of righteous anger and courage and vision. The person right now standing up to the government forces in Libya is not being sustained by their tweets or their Facebook postings. By the same token, computers don't educate children. Real education happens because of a personal connection between a teacher and a student. (Gladwell, 2011)

I begin a discussion of multiliteracies pedagogy with Gladwell's story to suggest that technological concerns facing literacy scholars and early childhood educators have relational backdrops. The many changes, even revolutions, of recent years include the challenge of how to theorize, adapt to, reconcile, and encourage teaching with new technologies of literacy. This has become more pressing - and more difficult - in classrooms where what counts as literacy and 'appropriate' pedagogy are increasingly contested concerns. As the rich examples of multiliterate engagement in Hesterman's study demonstrate, intersections of technology and literacy provide opportunities to 
reconsider inherited models and definitions of literacy teaching in early childhood classrooms, to reimagine the contours of literacy pedagogy, and to explore new forms of engagement, authorship, and learning.

Early childhood classrooms are unique spaces of possibility for theorizing literacy and articulating new pedagogical approaches. Following Gladwell (2011), I want to investigate these sites of 'real revolutions,' beyond utopian promises of technologies, to suggest some of the relational, social, and contextual concerns new literacies invite, within which new literacy pedagogies are embedded. Revisiting examples from Hesterman's study, I suggest implications of regarding multiliteracy pedagogies in early childhood settings as relationally and culturally situated. If we are on the cusp - or in the midst - of a technological revolution in literacy research and teaching, what manner of revolution is it? What kinds of new (and old) pedagogical relationships might it invite? How can multiliteracy educators navigate new trends and technologies in ways that account for diverse social realities, political contexts, and relationships - in Gladwell's terms, the human challenges - that teachers and children encounter in early childhood classrooms?

\section{Why Multiliteracies?}

With the vanguard title of Assistant Professor of Multiliteracies in Education, I encounter a variety of interpretations of what the term 'multiliteracies' signals. Is it related to technology? Is it inherently progressive? Intentionally vague, abstract, or provocative? In recent years, multiliteracies has become a flexible concept used to name and frame a range of local projects. In its original conception the term multiliteracies was adopted by the New London Group (1996) to address two related trends: increasing cultural and linguistic diversity of learners; and the changing landscape of literacy, including the rise of new technologies. In the years since the New London Group, new technologies of literacy have proliferated at a pace beyond what could have been anticipated in 1996. Literacy researchers have become interested in pedagogical implications of what have been variably termed 'new literacies' or 'digital literacies,' documenting the scope and substance of children's new literacy practices, and the range of innovative ways teachers continue to invent to incorporate new literacies into their practices. Much of this work is critical, and cuts against the grain of literacy policy in contexts such as the United States, where literacy legislation continues to restrict rather than invite children's full literate lives into classrooms.

The best multiliteracies research interweaves concerns with new literacies with important questions of diversity, identity, and politics. Foregrounding political contexts tempers temptations to regard technology as powerful - or power - in and of itself, rather than a means to power, one that might support more equitable or democratic possibilities for learning, or more oppressive ones (Street, 2011). Foregrounding social contexts counteracts idealizations of new literacies as technical, even deterministic, fixes to human problems, highlighting teachers' and students' intellectual work, diverse identities, and the epistemic dimensions of classroom relationships.

Among the many intriguing images Hesterman includes among the data in her study is a picture of two girls looking together at a picture book (Figure 1). The book is opened to an image of what appears to be a red fox. A computer in the background displays images of children. Hesterman frames her interesting analysis around uses of technology. How are these technologies shaped by other dimensions of learning? What kind of literacy engagement is this?

Two girls sit shoulder to shoulder. Each holds a page of a book, sharing a physical and interpretive space. The book appears to be Wombat Stew by Marcia Vaughan (2009). The 'fox' is likely a dingo, a wild dog unique to Australia. Above the onscreen images is the heading 'We had lots of fun making wombat stew' - suggesting how this text was a springboard for a class cooking activity, imagined or real. Above the computer screen is a bulletin board displaying children's paintings of various animals, including what seems to be a kangaroo.

This classroom literacy practice signals the unique social and cultural context within which it is embedded. The girls, only partially visible in the frame, appear to be of varied ethnicity, bringing unique cultural backgrounds and experiences to bear on their shared reading. What is their relationship? How is this moment embedded within broader social affiliations and communities, within and beyond classroom walls? Technology is a part, but not the primary aspect, of their 
engagement. What other factors are at play? In what ways do language, culture, and identity shape their interaction?

Rather than 'autonomous' tools, technology, like teaching, should be regarded as situated social practices (Street, 1995). These practices are inextricably shaped by social, political, cultural, and institutional contexts. This literacy event - two children reading together - is, to borrow from philologist and literary critic Erich Auerbach (1946/1968), 'fraught with background': shaped by unique family histories, and linguistic and cultural diversity; children's individual and shared interests, as well as external claims about their abilities and identities; institutional expectations, and the availability (or lack thereof) of material resources; contestation about literacy and the appropriate roles of literacy teachers. Given this complexity, is it any wonder that Leah, the teacher in this classroom, expresses concerns about how technology is (or is not) supporting her own and her students' learning?

\section{How is Teaching Multimodal?}

Another image from early childhood practice: In a classroom in Vermont in the 1970s, children have collaborated on building an enormous sculpture with blocks. Nearly six feet high, it stands at the center of a network of smaller buildings in an imagined city. On any given day in this small school, children are 'in multiage groups or alone, engaged with paint, blocks, cardboard and paper, sewing materials, cooking supplies, woodworking materials, books of all sorts, maps, globes, timelines, a wide variety of mathematical equipment, and natural science supplies and tools' (Carini, 2000, pp. 1-2). How is this learning? How is it related to literacy?

Teaching has always been multimodal. This is particularly true in early childhood contexts, like the classroom described above, where children are routinely invited to engage with a variety of materials and performances. Analyzing the variety of modes and media shaping literacy learning in addition to linguistic aspects - visual, aural, gestural, kinaesthetic - and describing pedagogy in terms of design metaphors has been taken hold of by researchers (e.g. Jewitt, 2005; Walsh, 2010) interested in making sense of learning in the midst of the rapidly changing contemporary landscapes of literacy. Technology is sometimes the focus of multimodal research. Yet the significance of this work is in how it furthers understandings of the social realities of teaching and semiotic affordances of different kinds of texts and forms of interaction with them.

The best multimodal work is fundamentally critical, charting new forms of literacy engagement that locate children as authors and rhetors (Kress, cited in Bearne, 2005). Multimodality challenges educational stakeholders, including teachers and researchers, to take children and their work seriously. As Jewitt (2005) notes, a multimodal approach 'enables these semiotic resources to be attended to and moves beyond seeing them as decoration.' This entails new forms of pedagogy, new forms of assessment, and new conceptual frameworks for making sense of situated, multimodal teaching and learning practices.

Another image from Hesterman's rich data (Figure 2): a tray, filled with sand, bits of straw, grass, seeds and rocks, blue cellophane for water, plastic and wooden farm animal figures representing characters in The Little Red Hen. The photograph of this diorama, including text from The Little Red Hen, adds, as Hesterman notes, an additional layer to this literacy practice. How does technology - in this case, a digital photograph - further these students' engagements?

Like the children involved in the construction of imagined cities in Vermont in the 1970s, before the digital camera was employed to capture the moment, these children were already engaged in a synesthetic marshalling of multimodal resources. A multimodal framework helps us to understand their work more three-dimensionally. It cuts against the grain of skills-based models for defining rigor and assessing literacy learning. The inclusion of digital photography provides additional affordances - further invitations for children to engage with literacy less as consumers and more as authors, reordering, reconstructing, rebuilding texts they engage with. These new engagements are inscribed within new social relationships, as well as new (and old) forms of inequity. 


\section{Taking an Inquiry Stance on Multiliteracies Pedagogy}

As Lytle (2008) notes, astonishingly absent from public discourse are images of the complex struggles that teachers engage in daily - with vision, courage, intellect, invention - in the service of teaching better. Each of the examples Hesterman explores - Leah's classroom, in which children remix picture books using the full range of available materials and imagination; and Whitney's classroom, where children are engaged in inquiries building from their own curiosities and interests in paper airplanes - are notable for the depth of children's social and intellectual investments, as well as how technologies shape their engagement. The images of students mapping the flight paths of their paper planes are striking in the ways technology supports new means for children to publish their interests. What is significant in these examples is how this work has emanated from teachers taking an inquiry stance (Cochran-Smith \& Lytle, 2009): regarding young children's interests not as marginal to instruction, but of central relevance. In each classroom a teachers' interest in her students provided openings for reimagining what is possible in early childhood pedagogy. Technology played a part in this process, and doubtless opened possibilities to explore new vistas of multiliterate engagement. Yet the substance of learning in each of these classrooms was embedded in the relationships that made learning possible, including a teacher's willingness to learn from her students.

Gladwell (2011) ended his convocation address with a challenge, noting, 'Technological problems are not the hardest part of the future. They are the easiest part. The hard parts are the human problems that accompany the rise of technology.' For literacy educators and researchers, the greatest challenge of multiliteracies pedagogy may well be in addressing the ways that new technologies interpolate teachers and children, inviting new forms of the human problems that teaching always entails. Investigating human dimensions of multiliteracies pedagogy involves interrogating fundamental assumptions about children and their capacities, viewing their cultural legacies and languages as powerful resources for teaching and learning, embedded in social contexts and social relationships. This requires working against the idea that as teachers our task is to imbue children with literacy skills - those of the past, present or future - to instead learn with them, including about new opportunities and new struggles that technologies afford.

Investigating human dimensions of multiliteracies pedagogy also entails countering fundamental misunderstandings about teachers' work, regarding their positions in classrooms as sites from which new understandings can be articulated, and rich theories of literacy learning can not only be applied, but also developed. While scholars have articulated powerful conceptual frameworks for making sense of literacy in local contexts, investigating the human dimensions of multiliteracies pedagogy requires surfacing the no-less rich theoretical perspectives generated by teachers engaged in the intellectual and relational labor of constructing and enacting theories of literacy from the locations of diverse schools, communities, and classrooms.

Educators and researchers interested in implications of multiliteracies for early childhood classrooms need to concern ourselves with technological problems - issues of equity are materially related to providing all children with access to new technologies. Access to new literacy tools is important, but it is only a beginning. Like the powerful new forms of engagement children continually invent with materials at their disposal, teaching with new forms of literacy requires continually learning from the constellation of children's myriad talents and interests, and having the courage and vision to break with our own and others' assumptions, to help students liberate their fullest potentials.

\section{References}

Auerbach, E. (1968) Mimesis: the representation of reality on western literature, trans. W.R. Trask. Princeton, NJ: Princeton University Press. Originally published 1946.

Bearne, E. (2005) Interview with Gunther Kress, Discourse, 26(3), 287-299. http: / / dx.doi.org/10.1080/01596300500199908

Carini, P. (2001) Starting Strong: a different look at children, schools, and standards. New York: Teachers College Press.

Cochran-Smith, M. \& Lytle, S.L. (2009) Inquiry as Stance: practitioner research in the next generation. New York: Teachers College Press. 
Gladwell, M. (2011) Convocation address, Trinity College, University of Toronto, June.

Jewitt, C. (2005) Multimodality, 'Reading', and 'Writing' for the 21st Century, Discourse: studies in the cultural politics of education, 26(3), 315-331.

Lytle, S.L. (2008) Practitioner Inquiry and the Practice of Teaching: some thoughts on 'better', Research in the Teaching of English, 42(3), 373-379.

New London Group (1996) A Pedagogy of Multiliteracies: designing social futures, Harvard Educational Review, 66(1), 60-92.

Street, B.V. (1995) Social Literacies: critical approaches to literacy in development, ethnography and education. New York: Longman.

Street, B.V. (2011) Response to 'Beyond New London: literacy learning and the design of social futures.' AERA Presidential Session, Annual Meetings of the American Educational Research Association, New Orleans, April.

Vaughan, M.K. \& Lofts, P. (2009) Wombat Stew. Lindfield, NSW: Scholastic Australia.

Walsh, M. (2010) Multimodal Literacy: what does it mean for classroom practice? Australian Journal of Language and Literacy, 33(3), 211-239.

ROB SIMON is assistant professor of multiliteracies in education in the department of curriculum, teaching and learning at the Ontario Institute for Studies in Education (OISE) of the University of Toronto. Dr Simon's research draws upon sociocultural theories of literacy to explore the relational and political dimensions of literacy teaching, learning, and teacher education from the perspectives of practitioners. He recently completed a multiyear study of the collaborative inquiries of a community of literacy teachers, and is the principal investigator for a Connaught-funded study that investigates the creation of an intergenerational network of pre- and in-service literacy teachers in Ontario, the Teaching to Learn research project. Correspondence: Dr Rob Simon, OISE/University of Toronto, 252 Bloor Street West, Toronto, Ontario M5S 1V6, Canada (rob.simon@utoronto.ca). 